\title{
Radiometric ages of Tertiary salic intrusions near Kong Oscars Fjord, East Greenland
}

\author{
D. C. Rex, A. R. Gledhill, C. K. Brooks and A. Steenfelt
}

As part of current geochronological studies of the Tertiary igneous province of East Greenland, samples from three subvolcanic complexes around Kong Oscars Fjord: Werner Bjerge, Kap Simpson, and Kap Parry (fig. 39) have been dated using Rb-Sr and K-Ar methods.

\section{Geology}

The Werner Bjerge complex (Bearth, 1959) is located immediately to the east of a major $\mathrm{N}-\mathrm{S}$ fault system separating the crystalline rocks of the East Greenland Caledonian fold belt

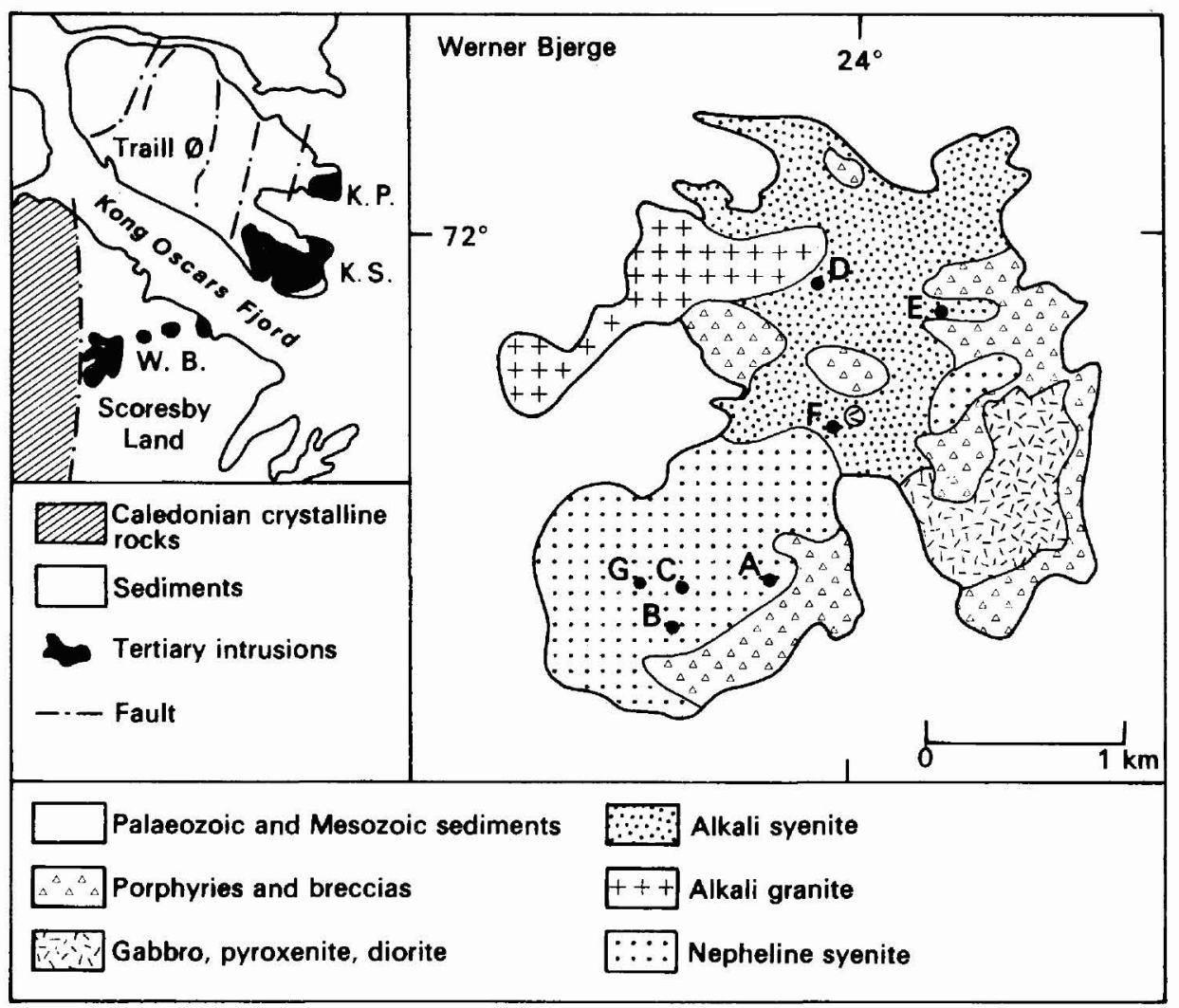

Fig. 39. Simplified geological map of Werner Bjerge subvolcanic complex central East Greenland (after P. Bearth, 1959). Letters A-G indicate locations of samples for Rb-Sr age determinations. W.B.: Werner Bjerge; K.S.: Kap Simpson; K.P.: Kap Parry. 
from younger sedimentary deposits. The intrusions (fig. 39) are emplaced in a sandstone sequence of Carboniferous to Triassic age. A volcanic cover consisting of acid, intermediate and basic porphyries, and volcanic breccias is preserved at several places. Intrusive bodies were emplaced in at least two phases, an older basic to intermediate suite which has not been included in this study, followed by a suite of alkaline granites, syenites and nepheline syenites. Numerous dykes of various compositions intruded the complex during and after the emplacement of the main igneous bodies.

The Kap Simpson complex (Schaub, 1942) and the Kap Parry complex (Schaub, 1942; Engell, 1975) both situated on Traill $\varnothing$ (fig. 39), are composed of syenitic and granitic, ring shaped intrusions enclosing downfaulted volcanics and sediments of the roof.

\section{Results}

The analyses of samples listed in Table 1 were carried out using standard techniques (Van Breemen \& Dodson, 1972). The whole rock Rb-Sr isochron (fig. 40) for the Werner Bjerge samples located in fig. 39 yields an age of $31 \pm 2 \mathrm{~m} . \mathrm{y}$. when all data points of Table 11 are included. This age agrees well with the biotite-feldspar Rb-Sr age of $27.1 \pm 2$ m.y. and is interpreted as the time of intrusion. However, the biotite K-Ar age of $28 \pm 1$ m.y. may be fractionally younger, although this is not adequately demonstrated by the data.

Beckinsale et al. (1970) tentatively interpreted a biotite K-Ar age of $28.7 \pm 2$ m.y. as a cooling age, but in the light of the present work can no longer be accepted. Gleadow \& Brooks (in prep.) obtained fission track ages on titanite ( $30.3 \pm 1.3$ m.y.) in agreement with the results reported here.

It is necessary to express a word of caution on the interpretation of the isochron, fig. 40 . The scatter of points is well outside the analytical error, indicating that all least one of the assumptions inherent in the Rb-Sr method is not fulfilled. In view of results from other East Greenland syenites (Pankhurst et al., 1976) it is tentatively suggested that there has been a variation in the initial ${ }^{87} \mathrm{Sr} /{ }^{86} \mathrm{Sr}$ ratio. Alternatively two ages may be represented as indicated in fig. 40. The broken line corresponds to an age of $33 \mathrm{~m} . \mathrm{y}$. , but the lower scatter on the solid line giving the age of $30 \pm 2 \mathrm{~m} . \mathrm{y}$. and initial ${ }^{87} \mathrm{Sr} /{ }^{86} \mathrm{Sr}$ of $0.7040 \pm 1$, leads us to consider it as a best estimate for the age of the intrusion.

Fig. 40. Whole rock $\mathrm{Rb}-\mathrm{Sr}$ isochrons for syenites of the Werner Bjerge subvolcanic complex, central East Greenland. The age and I.R. (initial ${ }^{87} \mathrm{Sr} /{ }^{86} \mathrm{Sr}$ ratio) indicated are based on the filled circles only.

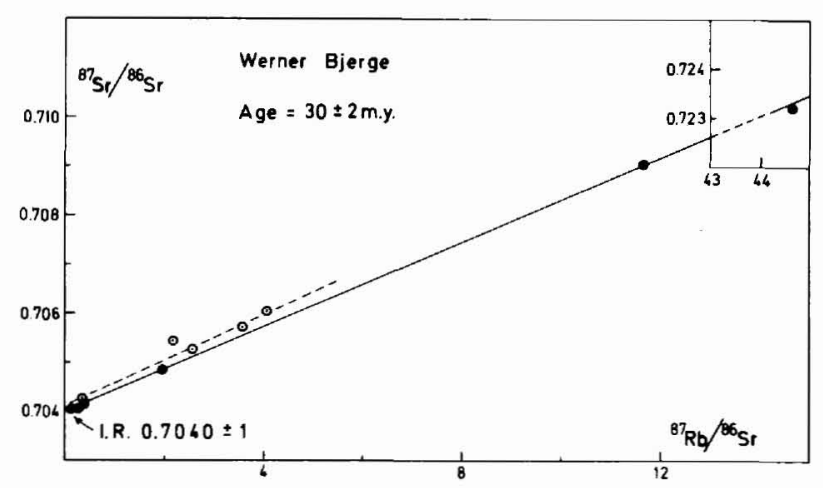


Table 12. $\mathrm{K}$-Ar age determinations from Werner Bjerge, Kap Simpson and Kap Parry

\begin{tabular}{|c|c|c|c|c|c|}
\hline $\begin{array}{l}\text { GGU } \\
\text { sample no. }\end{array}$ & Mineral & $\% \mathrm{~K}$ & $\begin{array}{l}\mathrm{Vol}^{40} \mathrm{Ar} \\
\mathrm{sec} / \mathrm{y} \times 10^{-5}\end{array}$ & $\underset{o}{* 0 \mathrm{Ar} \mathrm{rad}}$ & Age $m \cdot y$. \\
\hline \multicolumn{6}{|c|}{ Werner Bjerge } \\
\hline 241027 & biotite & 7.56 & 0.8286 & 69.7 & $28 \pm 7$ \\
\hline \multicolumn{6}{|l|}{ Kap Simpson } \\
\hline 241142 & biotite & 6.88 & 1.0254 & 75.2 & $38 \div 2$ \\
\hline 241142 & amphibole & 0.636 & 0.09469 & 46.9 & $38+2$ \\
\hline \multicolumn{6}{|l|}{ Kap Perry } \\
\hline \multirow[t]{2}{*}{124918} & anphibole & 1.35 & 0.2120 & 45.7 & 40.0 \\
\hline & (repeat) & & 0.2151 & 48.1 & 40.6 \\
\hline
\end{tabular}

The initial ${ }^{87} \mathrm{Sr} /{ }^{86} \mathrm{Sr}$ ratios obtained here (Tables $11 \& 12$ ) are similar to those reported by Pankhurst et al. (1976) for similar rock types in the Kangerdlugssuaq intrusion, suggesting that these syenitic to granitic magmas all originated in a similar manner.

\section{Acknowledgement}

J. E. Engell kindly provided the sample from Kap Parry.

\section{References}

Beckinsale, R. D., Brooks, C. K. \& Rex, D. C. 1970: K-Ar ages for the Tertiary of East Greenland. Bull. geol. Soc. Denmark 20, 27-37.

Bearth, P. 1959: On the alkali massif of the Werner Bjerge in East Greenland. Meddr Grønland 153, 4, $66 \mathrm{pp}$.

Brown, P. E., van Breemen, O., Noble R. H. \& MacIntyre, R. M. 1977: Mid-Tertiary igneous activity in East Greenland - the Kialineq complex. Contr. Miner. Petrol. 64, 109-122.

Engell, J. E. 1975: The Kap Parry complex, central East Greenland. Rapp. Grønlands geol. Unders. 75, 103-106.

Gleadow, A. J. W. \& Brooks, C. K. in prep: Fission track dating, thermal history and tectonics of igneous intrusions in East Greenland.

Pankhurst, R. J., Beckinsale, R. D. \& Brooks, C. K. 1976: Strontium and oxygen isotope evidence relating to the petrogenesis of the Kangerdlugssuaq alkaline intrusion, East Greenland. Contr. Miner. Petrol. 54, 17-42.

Schaub, H. P. 1942: Zur Geologie der Traill Insel (Nordost-Grönland). Eclog. geol. Helv. 35, 1-54. Van Breemen, O. \& Dodson, M. H. 1972: Metamorphic geochronology of the Limpopo Belt, Southern Africa. Bull. geol. Soc. Amer. 83, 2005-2018.

D. C. R. \& A.R. G.,

Department of Earth Sciences,

The University,

Leeds LS2 $9 \mathrm{JT}$,

U. $K$.
C. K. B., Institut for Petrologi, University of Copenhagen, $\emptyset$ ster Voldgade 10, $D K-1350$ Copenhagen $K$. 